\title{
Far Apart and Close Together: Fritz Haber and Chaim Weizmann
}

\author{
Tom Bielik ${ }^{\mathrm{a}}$ and Bretislav Friedrich ${ }^{\mathrm{b},{ }^{*}}$
}

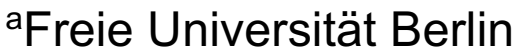 \\ Schwendenerstrasse 1, 14195 Berlin, Germany \\ ${ }^{\mathrm{b}}$ Fritz-Haber-Institut der Max-Planck-Gesellschaft \\ Faradayweg 4-6, 14195 Berlin, Germany
}

\begin{abstract}
Fritz Haber (1868-1934) and Chaim Weizmann (1874-1952) were both prominent German-speaking Jewish chemists with rather divergent views on Jewish assimilation and Zionism that only converged upon the rise of the Nazis to power in Germany. While Haber converted to Protestantism and followed the calling of a German patriot during World War One and the turmoil of the Weimar Republic, Weizmann became the leader of the Zionist movement whose efforts led to the founding of Jewish academic institutions in British Mandate Palestine and eventually to the creation of the State of Israel. Weizmann won the support of the British political establishment for the Zionist cause through his invaluable services to the British military as a chemist during World War One. Guided by the timeline of their encounters as well as their mutual correspondence, we trace the ever-closer relationship between these two towering figures of the 20th century. Had it not been for his ill health, Haber would have likely assumed a leading position at what is today the Weizmann Institute of Science in Rehovot as well as played a direct role in shaping other academic institutions, including The Hebrew University of Jerusalem, in the future State of Israel.
\end{abstract}

"Corresponding author. Email: bretislav.friedrich@fhi-berlin.mpg.de 


\section{Prelude}

The apparent first contact between Fritz Haber and Chaim Weizmann, dating back to March 1921, was indirect but consequential. As noted in Weizmann's autobiography (Weizmann 1949, 352):

It will be remembered that when I made my first trip to America, in 1921, I had been fortunate enough to enlist the co-operation of [Albert] Einstein. I learned later that Haber had done all he could to dissuade Einstein from joining me; he said, among other things, that Einstein would be doing untold harm to his career and to the name of the institute of which he was a distinguished member if he threw in his lot with the Zionists, and particularly with such pronounced Zionists as myself.

It would take nearly twelve years and the mediation of Weizmann's brother-in-law, Josef Blumenfeld (1901-1981), as well as Haber's son, Hermann Haber (1902-1946), for the two men to close the distance between them and to meet face to face. When they finally did, in London, Weizmann quickly warmed up to Haber: "I found [Haber], somewhat to my surprise, extremely affable" (Weizmann, 1949, 352). From then on, a rather congenial relationship had developed between Haber and Weizmann that hinged on Weizmann's Zionist project of building academic institutions in British Mandate Palestine and Haber's outstanding ability to help its advancement. In what follows, we will establish and follow the 
timeline of their mutual encounters - and of Haber's changing attitudes in response to the rise of Nazism - that nearly culminated in Haber's resettling to Palestine. Our principal guide will be their mutual correspondence (twenty nine letters retrieved from the Weizmann Archives in Rehovot), as well as correspondence with Albert Einstein, Hermann Haber, and others. Had Haber's ill health - and death - not cut short his journey to join Weizmann in Palestine, Israeli science could have benefitted not only from the involvement of Haber's pupils and coworkers/assistants, but also from the leadership of Haber himself.

But before making our way along the timeline of the personal encounters between Haber and Weizmann, let us examine how accurate Weizmann's assessment, quoted above, of what Haber had communicated in early 1921 to Einstein, Figure 2, actually was.

On 9 March 1921, prompted by the inauguration of Warren Harding (1865-1923) as U.S. President five days earlier, Haber wrote a letter to Einstein, in which he indeed urged his friend not to take part in Weizmann's trip to the U.S. and the U.K. However, the justification that Haber had given was quite different from that recorded in Weizmann's memoirs.

Harding's election shattered hopes that the U.S. would continue its attempts, made by Harding's predecessor, Woodrow Wilson (1856- 
$1924)^{1}$, to mitigate the harsh and unrealistic terms ${ }^{2}$ of the Versailles Treaty, pressed for by the British and French governments. Moreover, America was, technically, still at war with Germany at the time, and its joining the League of Nations was nowhere in sight; in fact, it would never happen (Dean, 2004).

As during World War One, Haber made Germany's problems his own: In order to alleviate the burden of the war reparation payments mandated by the Versailles Treaty, Haber launched a secret project aimed at extracting gold from seawater (Hahn, 1999; James, 2011, $59-60) .^{3}$

Thus it was the context of the grim political realities of the day and of Haber's personal engagement in easing Germany's predicament (Friedrich, 2019) that led Haber to write to Einstein the following lines (Fritz Haber to Albert Einstein, 9 March 1921):

It is the friendship of many years that forces me to write to you today. ... If at this point in time you ostentatiously fraternize with the English and their friends, the people [in Germany] will

\footnotetext{
${ }^{1}$ As we write this essay during the COVID 19 pandemic, we cannot but note that Wilson contracted the $1918 \mathrm{~A} / \mathrm{H} 1 \mathrm{~N} 1$ influenza ("Spanish flu") during the Paris peace treaty negotiations and it was while weakened on his sickbed in April 1919 that he yielded to the pressure from the Allies to abandon much of the spirit of his "Fourteen Points" except for the last concerning the League of Nations (Barry 2005, 381-388).

${ }^{2}$ French Prime Minister Georges Clemenceau: "The only way to avoid future wars is to destroy Germany, as we know it! The German people have shown they are evil!" (The Supreme Council of the Treaty of Versailles, 12 January 1919).

${ }^{3}$ The project launched in 1920 was scrapped in 1926, due to the low concentration of gold in seawater.
} 
regard it as a proof of the disloyalty of the Jews. So many Jews went into the war [WWI], died, and ended up in misery, without complaining about it, because they saw their service as a [patriotic] duty. Their lives and deaths have not eliminated antiSemitism, but have relegated it, in the eyes of those who shoulder the honor and greatness of our country, to [the category of] base hatefulness and ignobility. Do you wish to erase through your behavior what German Jews have achieved with their blood and suffering?

Einstein's answer (Albert Einstein to Fritz Haber, 9 March1921) was prompt (on the same day) and resolute, however with elements of non sequitur:

A few weeks ago ... a valued local Zionist visited me to hand over to me a telegram sent by Prof. Weizmann in which the Zionist Organization [WZO] was asking me to join some German and English Zionists on their trip to America to seek council on educational matters in Palestine. ... Despite my international mindset I feel obliged to stand up for the persecuted and morally oppressed members of my tribe [Stammgenossen], whenever it is somehow in my power. So I cheerfully accepted ... Therefore, [my participation in the U.S. trip] is much more an act of loyalty rather than disloyalty.

Then Einstein continues in a more to-the-point manner: 
No reasonable person can reproach me for disloyalty to my German friends. I received a number of attractive calls from Switzerland, the Netherlands, Norway, and England - and I turned them all down, without even thinking about accepting them.

Subsequently, Einstein adds a qualification:

By the way, I didn't do this out of attachment to Germany, but to my dear German friends, of which you are one of the most distinguished and benevolent. Attachment to Germany's political establishment would be for me, a pacifist, unnatural.

On his two-month tour of America and Britain as member of Weizmann's Zionist delegation, Figure 3, Einstein was treated as a celebrity (Illy, 2006). In his speech at the University of Manchester, which bestowed on him an honorary degree, he made use of his celebrity status to urge his audience to help overcome psychological barriers between German and British scientists (Stoltzenberg 1998, 394). Back in Berlin, Einstein's success abroad was regarded as homage paid to a German scientist - and no incidents related to Einstein's trip are on record. However, serious incidents followed not long thereafter, as the anti-Semitic (and anti-socialist) conspiracy theory of a "stab in the back" was taking hold in Germany (Barth, 2003). One of the early culminations of the hate campaign it incited was the assassination of Weimar's foreign minister Walter Rathenau, on 24 June 1922. Rathenau, a visionary industrialist of Jewish 
descent (Fritz Stern, 1999, 165-196), belonged to Haber's and Einstein's circle. In the aftermath of Rathenau's murder, Einstein, heeding the advice of his friends, temporarily left Germany for Asia as a safe haven. ${ }^{4}$

\section{Chronicle of personal meetings between Fritz Haber and Chaim Weizmann and their context}

\subsection{First meeting (London, 1932)}

Despite many common acquaintances, Haber and Weizmann were introduced to each other in person as late as 1932 - by their family members (the exact date of the meting is unknown). Josef Blumenfeld, Weizmann's brother-in-law, owned the chemistry company Societe de Produits Chimique des Terre Rares, based in Paris. Hermann Haber (1902-1946), the son of Fritz Haber and Clara, nee Immerwahr (1870-1915), worked for Blumenfeld's firm as a chemist (Stoltzenberg, 1998, 361).

At their amicable meeting in London, ${ }^{5}$ Haber was still the omnipotent German Geheimrat (privy councilor), see Box 1, while Weizmann, a British subject, was the leader of the Zionist movement, see Box 2. A year earlier, Weizmann was voted out of office as president of the World Zionist Organization. Disappointed by the disapproval of his

\footnotetext{
${ }^{4}$ On his Asian journey, Einstein was notified of winning the Nobel Prize in Physics for 1921.

${ }^{5}$ This meeting, like others in London, likely took place at the Russell Square Hotel in Bloomsbury.
} 
liberal political leadership, Weizmann concentrated on establishing a new biochemistry research institute in the town of Rehovot in Palestine, with the support of the British Zionist sympathizers Israel and Rebecca Sieff (Weizmann, 1949). This was far from a mere distraction for Weizmann. As Fritz Stern put it (Fritz Stern, 2016, 231),

For most liberals at the time, science was an unquestioned good, the fullest expression of human reason and human genius, an obvious instrument of human progress.

At their London meeting, Weizmann outlined his project in Rehovot to Haber, whereupon Haber "invited [Weizmann] to visit him at his research institute [in Berlin]" (Weizmann, 1949, 352).

\subsection{Second Meeting (Berlin, 5 December 1932)}

Weizmann accepted Haber's invitation and visited him at his Kaiser Wilhelm Institute (KWI) for Physical Chemistry and Electrochemistry in Berlin-Dahlem on 5 December 1932 (Chaim Weizmann to Eva Erleigh, 4 December 1932; Chaim Weizmann to Abraham Halevi Frenkel, 5 December 1932; Chaim Weizmann to Abraham Halevi Frenkel, 7 December 1932), less than two months before Adolf 
Hitler's rise to power in Germany. ${ }^{6}$ Here is how Weizmann described his visit (Weizmann, 1949, 532):

It was a magnificent collection of laboratories, superbly equipped, and many sided in its program, and Haber was enthroned as dictator ... He was not only hospitable; he was actually interested in my work in Palestine. Frequently in our conversation on technical matters, he would throw in the words: "Well, Dr. Weizmann, you might try to introduce that in Palestine."

In fact, Weizmann was impressed by what he saw in Dahlem to the extent that he decided to model what was to become the Daniel Sieff Research Institute on Haber's KWI.

In a letter from Nice, Haber thanked Weizmann for his visit in Berlin and the two notes that Weizmann wrote to him since, apologized for not replying earlier, expressed his appreciation for Weizmann's friendship, and provided advice concerning the acquisition of research chemicals (Fritz Haber to Chaim Weizmann, 23 December 1932). Quite striking about this letter is what it does not mention, namely the looming political catastrophe in Germany. This is alluded to only in the following letter that Haber sent to Weizmann on 21 May 1933 from Munich, where he was visiting his bosom friend Richard

\footnotetext{
${ }^{6}$ In fact, Haber spent these two months recuperating in Cap Ferrat near Nice and only returned to Germany after Hitler became German Chancellor on 30 January 1933 (Stoltzenberg, 1998, 574).
} 
Willstätter (1872-1942) ${ }^{7}$, see Figure 4. Although Haber did not explicitly mention his own predicament under the Nazi rule, he noted that Willstätter was reluctant to even consider moving out of Munich.

And a predicament it was: Soon after the promulgation of the "Law for the Restoration of the Professional Civil Service" - designed to exclude Jews and political opponents from civil service positions in Nazi Germany - on 7 April 1933, Haber found himself under the obligation to dismiss his coworkers of Jewish descent from the KWI (twelve out of forty-nine, Szöllösi-Janze, 1998, 651). ${ }^{8}$ Under a threat from the Kultusministerium [Ministry of Science, Education, and Culture] that the Society would come under a Nazi commissioner should the law not be enforced immediately and a concurrent pressure from the Kaiser Wilhelm Society, Haber dismissed, on 29 April 1933, his assistants Ladislaus Farkas (1904-1948) and Leopold Frommer (1894-1943) (Szöllösi-Janze, 1998, 656). The next day, Haber resigned in protest against the law from all his positions covered by it. Haber submitted his memorable letter of resignation on 30 April 1933 to the infamous Kultusminister Bernhard Rust, in which he noted (Fritz Haber to Bernhard Rust, 30 April 1933):

My sense of tradition requires of me that ... I only choose staff members according to their professional abilities and character, without regard to their racial make-up.

\footnotetext{
${ }^{7}$ Like Haber, Willstätter was a Nobel Prize winning chemist. He was awarded the 1915 Prize "for his researches on plant pigments, especially chlorophyll." 8 The law did not apply to Haber himself, as there was a clause that exempted the veterans of World War One who served on the front.
} 
The resignation was to take effect on 30 September 1933, the day the law entered into force. So when Haber wrote to Weizmann on 21 May 1933, he was already in limbo - without a job beyond the summer term or a plan for his future whereabouts. This letter to Weizmann also contains a reference to a lost letter sent by Weizmann to Hermann Haber on 14 May 1933, together with an assurance that that letter's content had been faithfully communicated to Haber by his son. However, what the content was we can only partly infer from Haber's 21 May 1933 letter, where he writes:

As for [Ernst] Bergmann I will talk to him in a few days when I return to Berlin and inform him about your really generous and most important offer and will recommend [to him to accept] it.

Ernst David Bergmann ${ }^{9}$ (1903-1975) was an assistant of Haber's colleague at the Berlin University, Wilhelm Schlenk (1879-1943), and Haber may have recommended him earlier to Weizmann for the Sieff Institute. By mid-May 1933, Haber's attempts to help junior Jewish scientists to find employment abroad was already in full swing. Providing such help would be one of Haber's main preoccupations until his death eight months later. Haber would also provide financial assistance to the suddenly unemployed members of his KWI from his private "Haber Fund." Several of them, such as the scientists Adalbert

\footnotetext{
${ }^{9}$ Ernst David Bergmann (1903-1975), a German-born Israeli nuclear scientist and chemist (Deichmann and Travis, 2004).
} 
and Ladislaus Farkas and the secretaries Rita Cracauer [spelled also Krakauer] and Irene Sackur, would emigrate to Palestine.

Ladislaus Farkas would assume the chair of physical chemistry at The Hebrew University of Jerusalem in 1936, the post slated originally for Fritz Haber, and become the founder of the school of physical chemistry in Israel. His highly acclaimed work on photochemistry, gas-phase reactions, and especially on ortho-to-para hydrogen conversion and deuterium launched at Haber's institute and continued at Cambridge lent him the status needed for the post (Rideal, 1949). Among his wide-ranging nation-building activities was his involvement in the founding of the Research Council of Israel.

Rita Cracauer (1891-1954) was Haber's secretary since 1917 - and the "soul" and "memory" of his KWI (James, 2011, 106-108). From 1935 until 1948 she took over as secretary to Chaim Weizmann at the Sieff Institute (Chaim Weizmann to Bruno Rosenfeld, 24 September 1935).

Haber was also in negotiations on his own behalf - among others, with the French minister of education Anatole de Monzie (1876-1947) about a position in Paris and with Frederick Donnan (1870-1956) and Sir Harold Hartley (1878-1972) about a research fellowship in London or Oxford, respectively (Hermann Haber to Chaim Weizmann, 26 July 
1933). To Sir William Pope $(1870-1939)^{10}$, Haber wrote (Fritz Haber to William Pope, 4 August 1933):

My most important goals in life are that I not die as a German citizen and that I not bequeath to my children and grandchildren the civil rights of second-class citizenship, as German law now demands ... The second thing that's important to me is to spend my last years in a scientific community, with honor but without heavy duties.

In the end, Haber would accept Pope's invitation to join him in Cambridge, see below.

\subsection{Third meeting (Paris, 10 August 1933)}

Haber left Berlin on 5 August 1933 - unawares that he would never return. His first destination was Santander in Spain, where the officials of the International Union of Pure and Applied Chemistry (IUPAC) were to hold a preparatory meeting on August 9-20, 1933 for the forthcoming 1934 IUPAC Congress (Monge, 2008). Joined on the trip by Richard Willstätter, Haber made a stopover in Paris to see Weizmann again. They met on 10 August, in the presence of Willstätter and Weizmann's assistant Ernst David Bergmann (Chaim Weizmann to Leonard Ornstein, 13 August 1933).

\footnotetext{
${ }^{10}$ Pope had worked for the British Chemical Warfare Service in World War One - for which he developed a new synthesis of mustard gas.
} 
This was a key moment in Haber's new life in exile, as Weizmann laid out his detailed plans for the Sieff Institute and offered both Haber and Willstätter leading positions there. In his autobiography, Weizmann recollects the circumstances and the way he extended his invitation to Haber (Weizmann, 1949, 353) ${ }^{11}$ :

[l] found [Haber] broken, muddled, moving about in a mental and moral vacuum. ... The shock had been too great. He had occupied too high a position in Germany; his fall was therefore all the harder to bear. ... I began to talk to him then about coming out to us in Palestine, but did not press the matter. I wanted him first to take a rest, recover from his shock and treat his illness [angina pectoris] in a suitable climate.

In addition, Weizmann offered Haber to make use of his connections at the British Foreign Office to help Haber to get out of Germany without having to pay the emigration tax [Reichsfluchtsteuer] (Hermann Haber to Chaim Weizmann 26 July 1933; Szöllösi-Janze 1998, 688).

\footnotetext{
${ }^{11}$ Weizmann places this meeting with Haber (after their second meeting, in Berlin, and before their fourth meeting, in Zermatt) in London rather than in Paris. However, we found no evidence that Haber and Weizmann met in London upon Haber's departure from Germany for Santander and believe that Weizmann was, in fact, describing Haber's state during their third meeting on 10 August in Paris. Haber stopped by briefly in London in mid-July, and expressly let himself be excused by Hermann Haber for not having had the time to see the Weizmanns then (Hermann Haber to Chaim Weizmann, 26 July 1933).
} 
Haber understood Weizmann as suggesting that, in the coming years, he would spend regularly the winter terms in Palestine, helping Weizmann with setting up the Sieff Institute. But before committing, Haber wanted to see the place and the people first and offered to visit Rehovot at the beginning of $1934 .{ }^{12}$ However, what he was apparently most eager to know was Einstein's opinion about the whole matter (Szöllösi-Janze 1998, 684-685). Still from Paris, Haber wrote to Einstein to update him about his situation, pleaded with him to make peace with Weizmann, ${ }^{13}$ and made a confession: "I never felt so Jewish as now." Haber also noted that he had been invited three times to date to come to Palestine: For the first time by Weizmann, ${ }^{14}$ for the second time by Abraham Shalom Yehuda, ${ }^{15}$ and most recently by Weizmann again at their meeting in Paris (Fritz Haber to Albert Einstein, August 1933). Upon his arrival in Santander, Haber received Einstein's reply (Albert Einstein to Fritz Haber, 9 August 1933) - a "terrible letter" (as he characterized it to his son Hermann) that

12 Through his son Hermann, Haber made the additional point that he would be glad if Albert Einstein, James Franck, and Richard Willstätter joined him in Palestine and would be rather reluctant to resettle there if they did not (Hermann Haber to Chaim Weizmann, 21 May 1933).

${ }^{13}$ By Fritz Stern's account (Stern, 2016, 159), "Haber sought to mediate between Weizmann and Einstein, who had had a falling-out over The Hebrew University [of Jerusalem] in particular and Zionist disregard of Arabs in general."

${ }^{14}$ We are not sure what Haber meant by this first invitation from Weizmann.

${ }^{15}$ Haber was approached by Yehuda, who would, in fact, become known for his "nefarious campaign" to remove Weizmann and Judah Leon Magnes from the leadership of The Hebrew University of Jerusalem (Weizmann to Magnes, 5 September 1933). Without mentioning any of it to Einstein, Haber was in fact, in his only meeting with Yehuda, exposed to and alarmed by this campaign (Hermann Haber to Chaim Weizmann, 26 July 1933). 
showed that the "Apocalypse of mistrust" among the Jews "has not only begun but was far advanced" (Fritz Haber to Hermann and Marga Haber, August 1933; Szöllösi-Janze, 1998, 684). Apart from expressing satisfaction that Haber's "love for the blond beast has cooled off a little," Einstein's letter teemed with sarcasms aimed at both Weizmann and the Hebrew University and further exacerbated Haber's misgivings about moving to Palestine. Drawing on the unqualifiedly positive attitude of Haber's trusted friend James Franck towards Weizmann, Haber set aside Einstein's advice to "keep away" from Palestine "for as long as a conscientious and competent leadership is not in place there" and wrote a friendly letter to Weizmann from a stopover in Basle on his way to Berlin (Fritz Haber to Chaim Weizmann, 24 August 1933) $)^{16}$ :

As far as I'm concerned, I will travel to Berlin tonight to see whether my resettlement to a different country will be connected with those considerable difficulties [emigration tax], or whether I will be able to handle the matter on my own. I seek your permission to make use of your offer to help, if need be. My wish to visit you and your wife this winter at the beginning of next year in Palestine remains unchanged.

16 This letter may have been written earlier and the date added in another hand. 
However, the next day, upon learning that Weizmann was vacationing in Zermatt, Haber decided to pay him a visit, ignoring the warnings of his doctors, including Rudolf Stern's, that he should avoid high altitudes because of his heart condition (Zermatt is located at the foot of the Matterhorn, at about $1600 \mathrm{~m}$ ).

Rudolf Stern (1895-1962), Haber's former coworker and brother of Hermann Haber's wife Marga (and father of the historian Fritz Stern (1926-2016)) started looking after Haber ever more often as Haber's health further deteriorated towards the end of his life. In his recollections, he noted (Rudolf Stern, 1963, 100):

Haber, tormented by the wish to find even now a place for useful work, was very much inclined to follow [Weizmann's] invitation, and, on the spur of the moment, paid a visit to Zermatt to talk things over with Weizmann, whose life's work he now considered with steadily growing admiration.

\subsection{Fourth Meeting (Zermatt, 25 August 1933)}

At and after the meeting in Zermatt, the plan for Haber's involvement in Weizmann's project in Palestine started taking concrete shape (Weizmann, 1949, 357; Chaim Weizmann to Ernst David Bergmann, 25 August 1933).

Haber's high-altitude visit with the Weizmanns was happening against the background of the $18^{\text {th }}$ Congress of the World Zionist 
Organization that was taking place in Prague from 21 August until 4 September 1933. As Weizmann explains in his memoirs, he did not intend to attend the Congress, despite the importance for Jews to speak in one voice during the crisis brought about by the rise of the Nazis to power in Germany (Weizmann, 1949, 353-354):

I had refused to attend [the Congress], not wishing to be involved in any political struggle. During the dinner [with Haber, Weizmann's wife Vera and their son Michael] repeated [phone] calls came from Prague, and frantic requests that I leave Zermatt at once and betake myself to the Congress. I persisted in my refusal, and though I said nothing to Haber about [the reason for] these frequent interruptions, except to mention that they came from Prague, he guessed their purport from something he read in the papers, and he said to me, with the utmost earnestness: Dr. Weizmann, I was one of the mightiest men in Germany. I was more than a great army commander, more than a captain of industry. I was the founder of industries; my work was essential for the economic and military expansion of Germany. All doors were open to me. But the position which I occupied then, glamorous as it may have seemed, is as nothing compared with yours. You are not creating out of plenty - you are creating out of nothing, in a land which lacks everything; you are trying to restore a derelict people to a sense of dignity. And you are, I think, succeeding. At the end of my life I find myself a bankrupt. When I am gone and forgotten your work will stand, a shining monument, in the long history of our people. 
Do not ignore the call now; go to Prague, even at the risk that you will suffer grievous disappointment there.

Haber's speech in Zermatt is often quoted, but seldom with the point about the significance that he attributed to Weizmann's work. Weizmann "did not go to Prague, much to Haber's disappointment," but he (Weizmann, 1949, 354)

took the opportunity to press upon [Haber] our invitation to come out to Palestine and work with us. I said: "The climate will be good for you. You will find a modern laboratory and able assistants. You will work in peace and honor. It will be a return home for you - your journey's end." He accepted with enthusiasm and asked only that he be allowed to spend another month or two in a sanitarium.

What happened next is captured in Rudolf Stern's recollections (Rudolf Stern, 100):

On leaving Zermatt, Haber suffered a complete breakdown in the little town of Brig; he himself thought it was an apoplectic fit while, from his later descriptions, I was more inclined to consider it a heart failure. Anyhow, he recovered sufficiently to be able to travel to the Swiss sanitarium in Mammern where he spent the whole of September under competent medical care and in the company of his always helpful and understanding stepsister, Else Freyhan. 
Still from Brig, Haber reported about his state to Weizmann (Fritz Haber to Chaim Weizmann, August 1933):

I'm again in full possession of my body, speech, and mental capacity and have only thoroughly spoilt the summer holiday car trip for my son Hermann and his French friends. No more will I ride up to the elevation of 1600 meters and then down from there again, but I am glad that my last mountain trip has given me the opportunity to meet you and your wife and Mrs. Hadassah Samuel ${ }^{17}$ as well as to see, for the first time in my life, the Matterhorn, which occupies a very special place among mountains, as you do among men. ... I kindly request your permission to stay in touch with you with regard to Palestine and to the eventual help that I may need in order to be able to extricate myself from Germany. I would be most grateful if you could write me a letter inviting me to spend a part of the year in England and the rest in Palestine, should the English climate be too rough for me. I could then use this letter with the lower authorities in Germany in the case the higher authorities make no trouble for me when I will be leaving the country, without the need to involve the Foreign Office. ... I have two fully furnished

\footnotetext{
${ }^{17}$ Hadassah Samuel (1897-1986) was a Zionist activist. She married Edwin Samuel, the son of Herbert Samuel (1870-1963), the British liberal politician of Jewish descent who became, controversially, the first Commissioner for Palestine, serving from 1920 until 1925. David Samuel (1922-2014), the son of Edwin and Hadassah Samuel, was one of the founding faculty members at the Weizmann Institute of Science, working in the fields of physical chemistry and later neurobiology.
} 
houses [directorial mansion in Dahlem and a farmhouse in Witzmanns near Bodensee] and the furnishings will have to go either to France [apparently to Hermann Haber] or to Palestine.

We note that the time at Zermatt was also highly stressful for Weizmann - because of the Zionist Congress - who took off as well: "I'm now here [in Merano] for the last 3 days trying to gain some peace" (Chaim Weizmann to Judah Magnes, 5 September 1933).

During the next couple of months, Haber stayed at the sanitarium [Kurhaus] in Mammern im Thurgau, regaining some of his strength, "reading [Arnold] Zweig's Palestine novel, ${ }^{18}$ which is set in your social surroundings" (Fritz Haber to Chaim Weizmann, 1933) - and, on 1 October 1933, bidding his farewell to his KWI coworkers in a letter addressed to Otto Hahn as the institute's interim director (Fritz Haber to Otto Hahn, 1 October 1933.

With Weizmann, Haber continued exchanging letters about plans for his move to Palestine, his poor health, and his financial concerns while extolling Weizmann's achievements.

Weizmann started implementing these plans on the Palestine side, as attested to by his correspondence with Haber and with his colleagues in Rehovot. The plans included setting up Haber's laboratory and finding a suitable accommodation for him (Chaim Weizmann to Judah Magnes, 5 September 1933; Fritz Haber to Chaim Weizmann, 5

${ }^{18}$ Probably "De Vriendt kehrt heim" [De Vriendt returns home]. 
October 1933). Weizmann was able to report to Haber on the progress achieved (Chaim Weizmann to Fritz Haber, 2 October 1933):

I am happy to inform you that the outer shell of the building is ready, and the people there are beginning with the inner outfit. ... I am assured that the laboratory will be in working order on January 1st, so that if we all get there during December, we shall find a great deal to do. I have instructed Palestine to look for accommodation $\ldots$ and would be glad to know approximately what accommodation you will require. Who will be travelling with you? Of course, at the beginning accommodation will be rather scanty, and perhaps Spartan, but we shall soon have comfortable quarters for you. Will you be taking some of your Library with you? And will your sister and your secretary be accompanying you?

Haber replied (Fritz Haber to Chaim Weizmann, 5 October 1933):

In any case, my situation requires further consideration, before I can make a final decision about whether to undertake such a long trip ... For such a trip I would need the company of my sister, Ms. [Else] Freyhan, as my health situation is uncertain ... I have considerably recovered since my breakdown [in Brig] ... but I don't think I can take upon myself to travel to the NearEast on my own. I intend to stay here until mid-October ... and then to travel to Orsellina [in the Locarno area of Switzerland] 
and stay there for a while, and from there continue by ship from Genoa either to Alexandria and from there to Cairo and Jerusalem to visit you and your wife; or should a suitable ship be available, sail directly from Genoa to Haifa.

Haber further ventures to recommend Ladislaus Farkas as his most suitable assistant - and potential successor should Haber assume the chair of physical chemistry at The Hebrew University of Jerusalem - and suggests to Weizmann to invite Farkas for a visit in London (Farkas was just about to start a fellowship in Cambridge).

In the letter, Haber goes on to describe his disappointment about the outcome of the $18^{\text {th }}$ Zionist Congress that did not result in re-electing Weizmann as WZO's President:

I certainly understand that under the [adverse] circumstances in Prague you could not have accepted the presidency. However, I was highly disappointed that the Congress participants could not, in light of the present situation, set aside their differences and unite in voting for you. They are lucky that the National Socialists in Germany give them more time - in that that they are not softening their position toward people of different views than theirs, but rather sharpening [their position] to the extent that my colleagues of purely Aryan descent are beginning to see the situation as unbearable and started looking for new jobs in foreign countries. 
Finally, Haber vents his views on what the rise of Nazism in Germany means for German and European chemistry and chemical industry and outlines his vision of the opportunity the decline on the European continent may open for Palestine and Turkey:

German chemistry dislodged, in about 1870, English chemistry from the leadership position, whereupon French chemistry, which in the time of Liebig had a great weight, dropped out as well. Now, I assume, the German position is up for grabs and the question is who will take it. ... The continuation of a great project with the help of people who were chosen in the first place according to their political views seems hopeless to me in Germany. And even if Palestine is not strong enough to take the place of Germany, your reorganization of the University of Jerusalem and the ongoing restructuring of the University of Istanbul will ignite a light in the east that has all it takes to become a bright light for the whole world.

Regarding his negotiations with the University of Cambridge and the emigration permit, ${ }^{19}$ Haber noted:

I conclude today with my kind request that you induce the [British] Foreign Office to communicate via the British Ambassador in Berlin to the Ministry of Finance [Reichsfinanzministerium] that the Vice-Chancellor of the

\footnotetext{
${ }^{19}$ Emigration without a permit - in violation of the Reichsfluchtgesetz - would have also resulted in denial of a state pension to Haber.
} 
University of Cambridge has invited me to work at the university as his permanent guest and that I am thinking about accepting this honorable offer, provided the German authorities will approve it and refrain from using the flight-from-the-Reich law [Reichsfluchtgesetz] against me.

In his letter of 15 October 1933, Haber made Weizmann privy to an additional complication: Haber was denounced in Berlin by the "secret police of the National Socialist Party" for a "conversation he had on 12 July 1933 with his English colleagues" in London (Fritz Haber to Chaim Weizmann, 15 October 1933). In this conversation, Haber allegedly made unflattering remarks about Hitler and expressed his intent to act against the Nazi regime. The Nazi authorities took the high road in handling the case and asked, on 23 September 1933, Max Planck, the President of the Kaiser Wilhelm Society, for his reaction. Haber responded that he was a "liberal" but denied involvement in any political activities (Szöllösi-Janze, 1998, 687). Weizmann acted promptly on the latest news and wrote to Haber: "I have seen my friends of the Foreign Office; though they can do nothing directly, they were very sympathetic and have given me some useful advice as to the means by which I can secure what I want" (Weizmann to Haber, 20 October 1933). Throughout, Haber was convinced that the University of Cambridge could help him get away with a tax-free exit from Germany - along similar lines with what Kemal Atatürk's government was doing for German immigrants to Turkey (Szöllösi-Janze, 1998, 688). 
At the beginning of November, refreshed by his sojourn in Mammern, Haber, accompanied by his stepsister Else, set out for Cambridge. They reached their destination, after stopovers in Paris and London, ${ }^{20}$ on 7 November. ${ }^{21}$

Weizmann did his best to support Haber during the time in Cambridge. Upon Haber's arrival there, Weizmann wrote the following (Chaim Weizmann to Fritz Haber, 10 November 1933):

I somehow feel that you are perhaps a little bit uneasy during these first few days at Cambridge, and I would like you to know how much I understand and sympathize with you; the first few days in strange surroundings are always difficult. But I am sure that that feeling will pass very soon, and that you will shortly be finding the atmosphere a congenial and friendly one in which you can carry on your work under really happy conditions.

During his nearly three-month stay in Cambridge, Haber had been visited by many of his former coworkers and colleagues, among them Michael Polanyi (1891-1976), Paul Harteck (1902-1985)22, Ladislaus

\footnotetext{
${ }^{20}$ Stoltzenberg suggests that Haber and Freyhan saw Weizmann briefly during their London stopover on 4 November 1933 (Stoltzenberg 1998, 610). ${ }^{21}$ In his perhaps incorrectly dated letter to Weizmann (Fritz Haber to Chaim Weizmann, 1 October 1933), Haber laid out his travel plans that included a stopover in London on 4 November 1933 and a reservation at the University Arms Hotel in Cambridge from 7 November on.

22 Unlike the others listed, Paul Harteck was not an émigré. After a stay funded by the Rockefeller Foundation with Ernest Rutherford at the Cavendish Laboratory, he would return to Germany and assume in 1934 the
} 
Farkas, and Max Born (1882-1970). A happy moment was a colloquium given by Haber's Dahlem coworkers in his room at the University Arms Hotel. As Haber's former "chief of staff," Hartmut Kallmann (1896-1978), recollected "a scientific discussion [unfolded] more wonderful than you can imagine" (Stoltzenberg 1998, 610-611).

In addition to all the activities reflected in his correspondence, Haber worked very hard on his science in Cambridge: he wrote there his last paper, on catalytic decomposition of hydrogen peroxide (Haber and Weiss, 1934), a paragon of thoroughness and ingenuity, nineteen printed pages long. According to Haber's stepsister Else, it cost him the "last ounce of his strength" (Stoltzenberg 1998, 612). The coauthor was Haber's Berlin assistant Josef J. Weiss (1905-1972). It was also in Cambridge where Haber would give his last lecture, on 23 January 1934 (Szöllösi-Janze, 1998, 691).

In his letter to Weizmann of 16 November 1933, Haber reveals the depth of his concerns regarding his emigration from Germany and his attempts to enlist IG Farben and the University of Cambridge, including Ernest Rutherford (1871-1937), in helping him. At the core of his worries is the issue of the emigration tax (Fritz Haber to Chaim Weizmann, 16 November 1933):

The Berlin tax consultant's message that he has to see me at once reaffirms my conviction that I cannot accept your invitation

chair in physical chemistry at the University of Hamburg, which was left vacant after Otto Stern's forced emigration (Klee, 2003) 
to come to Palestine before my emigration affairs in Berlin have been taken care of. What would I do if I were not a day's journey away from Berlin but 4 or 5 days?

Among the prominent German Jewish scientists whom Weizmann would have liked to win for the Palestine project was Max Born. Born was first sounded out by Einstein and subsequently talked to by Haber, in Cambridge, where Born too held a fellowship. However, Born declined the offer of a chair at The Hebrew University of Jerusalem, with a rationale that Haber reproduced to Weizmann in a letter (Fritz Haber to Chaim Weizmann, 29 November 1933). This letter attests to Haber's deep Jewish sensibilities and his identification with Jewish issues:

My task was easy, as I just had to find out how [Born] answered Einstein's inquiry. ... As [Born] joined [the University of Cambridge], he was given the hope [Haber's emphasis] that his appointment there will not be just for three years. Now, his reaction to "Palestine" is determined by his consideration for the attitude of his wife and children, and this attitude is not favorable. The wife is the daughter of a Jewish father but the granddaughter of a famous ur-Aryan German professor of jurisprudence [Rudolf von Jhering (1818-1892)] and, as it appears, she had been raised in the German Christian world and has raised [their] children, who are half-grown up, in the same way. Under these circumstances the possibility to feel at home in the Jewish world is full of uncertainty. This is 
exacerbated by [Born's] doubts about his ability to learn well enough in his lifetime a foreign language, that is Hebrew [Hebrew was the language of instruction at The Hebrew University of Jerusalem]. And he is doing too well in order to accept the position out of want. What's essentially in the way ... is the West-European upbringing [Bildungsrichtung] of the children. ... I have no doubt that [Born] would have liked to accept an invitation to spend a trimester in Jerusalem, if only the physicists here [in Cambridge], especially Rutherford, were not put off by it. He would decide to accept a permanent position in Jerusalem only if his stay there changed his WestEuropean outlook or if he were forced to it by external circumstances. ... This attitude has been prevalent in the generation of German citizens of Jewish faith ... where the [various] confessions became blended. ... I have no doubt that a colony of leading scholars in Jerusalem would be of uncanny appeal to new recruits. However, what deters people like Born in the first place is that his Jewish colleagues, of whom he named three, among them Ornstein [Leonard Ornstein (18801941)], who had been lured to Palestine before him, turned down the offer. [At his age of 50, Born] is not old enough to feel ... the perfect lack of thankfulness from the side of the Hitler world nor is he young enough to be easily changed from his [West-European] standpoint to the idealism of the new world in Asia [Minor] [the text in italics Haber wrote in English]. 
Whereupon Weizmann replied (Chaim Weizmann to Fritz Haber, 1 December 1933):

It makes one rather sad to think that distinguished people like Born do not feel any urge to make their contribution towards an at least partial solution of our problem - a problem incidentally, of which they are themselves the victims, and at the same time the partial creators by their intellectual attitude in the past, and even in the present. However, it seems that it is our fate to be thus regarded by certain of our distinguished men, and I am coming to resign myself to it. It only means that those of us who are conscious of the problem, and of our own responsibilities, have to make up by our efforts for those who stand aside.

For his $65^{\text {th }}$ birthday on 9 December 1933 , Haber received a great number of congratulatory letters, among them one from Carl Bosch (1874-1940), then Chairman of the Board of IG-Farben. ${ }^{23}$ Before he got down to replying, Haber was notified, via his Berlin attorney, that IG-Farben decided to sever its ties with Haber should he accept a position at a university in a former enemy country (Szöllösi-Janze, 1998, 690). Such stance by the influential company further diminished the chances of a settlement between Haber and the Nazi authorities regarding Haber's emigration. This true "stab in the back" led Haber to complain to Bosch, on the assumption that he was

${ }^{23}$ Carl Bosch, a 1931 Chemistry Nobel laureate, would become President of the Kaiser Wilhelm Society in 1937, a position he held until his death in 1940. Under his leadership, Haber's catalytic synthesis of ammonia was scaled up in the 1910s to what is since known as the Haber-Bosch process of ammonia's industrial production. 
unaware of his company's doings. Haber's letter served simultaneously as a reply to Bosch's birthday wishes (Fritz Haber to Carl Bosch, 28 December 1933):

You are today a man of great importance in the homeland that I have abandoned, in order to live the old days of my life in a foreign land. You offered me help ... and I took your words seriously. ... The only thing I want is to be released in honor from a situation in which I cannot continue to be without shame. ... I'm a welcome guest here until the end of my life. Don't you want to make it possible for me to spend the rest of my [life afflicted by] woefully poor health and declining scientific abilities in peace and with decency?

In his key letter to Weizmann (Fritz Haber to Chaim Weizmann, 6 January 1934), Haber made clear, on the one hand, that he will not be able to come to Palestine in the near future, and, on the other, that he has embraced the Zionist cause.

As for the former, Haber informed Weizmann about the lack of progress concerning his emigration from Germany: the visit by the British Ambassador at the German ministries in Berlin "on whose effect [Haber] built a skyscraper" was to no avail and "has contributed more to [Haber's] modesty than to [his] success." Haber's deteriorating health added a reason of its own for the need to postpone his trip to Palestine: 
Meanwhile, the condition of my heart is changing with the coming winter and increasing anxiety, and the thought that seemed self-evident to me, namely that I could take off for and reach Palestine in order to recuperate, has now changed due to my state of health into its very opposite. ... I presumed that you would travel to Palestine for Easter [sic] and inquired here with a physician about the possibility of going to Madeira this month. He warned me against this journey as too great an undertaking and has thereby implicitly forbidden my trip to Haifa. Added to the concern that the German authorities will cause me trouble when I'm far away is a new and greater fear that the trip would not improve but rather worsen my condition.

As for the latter, Haber offered the following reflections on Weizmann's project, Jewish history, and Zionism:

In truth, I do not envy you your great project. I feel with increasing urgency every day that only those things are worth doing that we venture to do out of a higher consideration. But for that we need strength and confidence in our physical endurance, and it seems to me that the conditions for your success depend increasingly on overcoming an inner deficiency of the Jews in my homeland that has not yet been stamped out by Hitler's Germany. [The German Jews] feel closer to the German state than to Zionism and [live] without the purity and simplicity of a spiritual direction of their own. Since Hitler's economic policy was met with success, the days of the Jewish 
prophets faded in the fog of a forgotten past and the overrating of a physically bearable existence has moved into the foreground of their interests again. No one who preaches from his desk about the Maccabees can escape being laughable, but no one who expects peaceful citizens to turn into Maccabees can escape a madhouse. I have known the wartime battlefields on which French and English Jews shot German Jews, just as French and English socialists shot German social democrats and that left behind strains of mortality that are painful to bear [a paraphrase of Goethe's Faust, verse 11954].

The Russian Jews are ahead of us, because they suffered during the days when in Germany we were seeking honor and respect. If the Americans recover economically, they will become Zionists again, as they had been before the Hitlerdays. But if their system of private capitalism fails, Palestine will have to make its ascent not with the help of [American] means but, in accordance with Bismarck's dictum, by means of blood and iron. I'm writing all this not as an opinion of a man who feels responsible but from the perspective of the age that the year 1933 has bestowed on me and with the wish to be as useful to you as my strengths allow and with my all best wishes for your success and the well-being of your family that has instilled a feeling of true friendship in my tired soul.

Haber also mentioned the concerns of his German friends about a war with England and its possible consequences for Haber: 
My German friends are in a strange mindset. They seriously believe in the possibility of an involvement in a war [between Germany and Britain], and instead of realizing that in such a case I would have the choice of either sitting in a civilian prisoner camp or fleeing from England, they keep busy contemplating the question of whether I would take the side of England and provide assistance to the English armament effort. How much bad conscience in things military must there be around in order for people to think in this way!

No record of Weizmann's reaction to this letter from Haber has been found.

In his next letter to Weizmann, Haber recounted the emotional problems he faced when submerged in a foreign culture in Cambridge - with repercussions for his ever more distant plans to move to Palestine (Fritz Haber to Chaim Weizmann, 15 January, 1934):

I'm afraid I haven't made myself sufficiently clear about what it means to move at my age to a land with a foreign language and way of life. I enjoy here all the conceivable formal friendship in the circle of fellow chemists. But I miss all those natural leadership activities that I had developed at home over 40 years. Whether I will be able to step out of this circle, in which you still enjoy a great deal of respect since your Manchester 
days, during this winter and conceive of anything else than a sojourn in a foreign sanitarium is as uncertain as crossing a lake on thin ice.

Before his departure from Cambridge, Haber wrote a letter addressed to the vice chancellor of the University in which he stressed that the "chivalry from King Arthur's time still [lived] among [English] scientists" and expressed a "strong hope" that he "will be able to return within a few weeks" to Cambridge (Stoltzenberg, 1998, 615616). At this time of humility and contrition, Haber also drafted his testament. In it, he expressed his wish to be buried alongside his first wife Clara, ${ }^{24}$ in Dahlem, if possible, or elsewhere "if impossible or disagreeable" (Stoltzenberg, 1998, 630).

\subsection{Fifth - and last - meeting (London, 26 January 1934)}

Haber departed from Cambridge on 26 January 1934. During a break in London the same day, he met Weizmann for the last time. Haber's son Hermann and Weizmann's brother-in-law Josef Blumenfeld were also present, as at the first meeting between Haber and Weizmann in London less than two years earlier. Not much is known about what was discussed at this meeting. Haber was weak and exhausted and Weizmann must have realized that Haber would not be joining him in Palestine any time soon.

\footnotetext{
${ }^{24}$ Clara Haber, herself a physical chemist, committed suicide after fourteen years of marriage with Haber (Friedrich and Hoffmann, 2017).
} 
Following their final meeting, Haber took off for Orsellina in southern Switzerland. At a stopover in Basle, he was joined by his son Hermann and his wife Marga as well as by Rudolf Stern and his wife. Here is Stern's recollection (Rudolf Stern, 1963, 102):

[Haber] more or less ignored his anginal pain, which grew steadily worse when the rough English winter set in. [Else's] entreaties to go south were in vain, although they were supported by frequent letters from his son Hermann and from me. Only when he had completed his paper [with Weiss], did he agree to go to the sanitarium in [Orsellina in the] Locarno [area]. He asked the young Habers and us to meet him in Basle. This we did on the morning of January 29, 1934. When he and his sister arrived at the Hotel Euler, all of us were frightened by the terrible change in his appearance. He was not able to talk for even a few minutes without experiencing severe angina.

Haber passed away, as a result of heart failure, in the evening of the same day, 29 January 1934, in his room at Hotel Euler in Basle (Rudolf Stern, 1963, 102).

In his condolence telegram addressed to Hermann Haber, Weizmann stated (Chaim Weizmann to Hermann Haber, 31 January 1934): 
Deeply shocked and distressed sad news your dear father's death science and humanity lose in him one of their greatest sons.

Einstein noted in his letter to Hermann and Marga that Haber's was "the tragedy of the German Jew: the tragedy of unrequited love" (Albert Einstein to Hermann and Marga Haber, after 29 January 1934). ${ }^{25}$

On 3 April 1934, the Daniel Sieff Research Institute was inaugurated, with Weizmann as its founding director. Richard Willstätter gave the inaugural speech, in which he extolled Weizmann's accomplishments and remembered his friend Haber.

The next day, on 4 April 1934, a cornerstone was laid for the institute's library building, see Figure 5. Among those in attendance were, apart from the host Chaim Weizmann, Ladislaus Farkas, visiting from Jerusalem, and possibly Haber's stepsister Else Freyhan. The new library building would provide a home for Fritz Haber's book collection ${ }^{26}$, bequeathed to the Sieff Institute by

\footnotetext{
${ }^{25}$ On the initiative of Max von Laue and Karl Friedrich Bonhoeffer, Haber's former KWI would be renamed, on 9 December 1952, after its founding director. Its full name today is Fritz-Haber-Institut der Max-PlanckGesellschaft.

${ }^{26}$ The arrival of the book collection in Haifa and subsequently at the Sieff Institute is mentioned, respectively in (Chaim Weizmann to Richard Willstätter, 10 September 1935) and (Chaim Weizmann to Richard Willstätter, 15 December 1935).
} 
Hermann Haber ${ }^{27}$. The original library of the Sieff Institute, named after Fritz Haber, was inaugurated on the second anniversary of Haber's death, 29 January 1936 (The Weizmann Institute of Science Archives). Today, the Fritz Haber Collection is a part of the main library of the Weizmann Institute of Science in Rehovot. It consists of science classics from Haber's time, often with a personal inscription by the author.

\section{Postlude}

In his autobiography, published fifteen years after Haber's passing, Weizmann characterized Haber as someone "who was [our emphasis] lacking in any Jewish self-respect. He had converted to Christianity and had pulled all his family with him along the road to apostasy" (Weizmann, 1949, 352). We wonder whether Weizmann, after witnessing at close range Haber's "reconversion" to secular Judaism and his growing sympathies for Zionism, did not mean to say "had been" instead of "was."

As Stefan Wolff pointed out, Haber in fact never stopped caring for Jews - and anti-Semitism remained his major concern. However, he had additional concerns and identities. Haber's conversion, at age twenty-three, happened in the aftermath of the public debate between an overt anti-Semite, Heinrich von Treitschke (1834-

\footnotetext{
${ }^{27}$ We note that, according to Else, Haber's son Hermann was "much more of a Jew" than his father and that it was Hermann who pushed the Palestine idea in the first place (Szöllösi-Janze 1998, p. 683). However, he would never settle in Palestine.
} 
1896), and a liberal, Theodore Mommsen (1817-1903). The latter called upon Germans to abandon "those loyalties and affiliations that divided them" (Mommsen 1880). Haber's embrace of Protestantism, to which he was exposed since high-school, may have also been motivated by Greek philosophy, which he studied passionately, especially Plato, with his emphasis on the spirit (Wolff 2018). According to Rudolf Stern's testimonial, "one has no right to throw doubt on the integrity of [Haber's] motives [for conversion]. It would be ridiculous to interpret his conversion as caused by ambition and opportunism, for it was performed at a period when Haber did not dream of an academic career but was firmly resolved to take over and enlarge the family business" 28 (Rudolf Stern, 1963, 88).

However, Willstätter rebuffed conversion for whatever reason, on principle: "One has to refrain from conversion to Christianity, 'because it is connected with rewards' [quoting Walter Rathenau]" (Willstätter, 1973, 396).

Regardless of their differences - between them and with him Weizmann cherished the memory of both Haber and Willstätter: In his office at the Sieff Institute, he kept, displayed side by side on his desk, their photographs, see Figure 6. Their silent presence

\footnotetext{
28 Haber's father, Siegfried Haber, owned a trading company dealing in dyes and pharmaceuticals. Fritz Haber, the only son, was the designated heir of the company.
} 
speaks volumes to curious visitors of Weizmann's quarters, now that they have been converted into a historic site. 


\section{Box: Fritz Haber (1868-1934)}

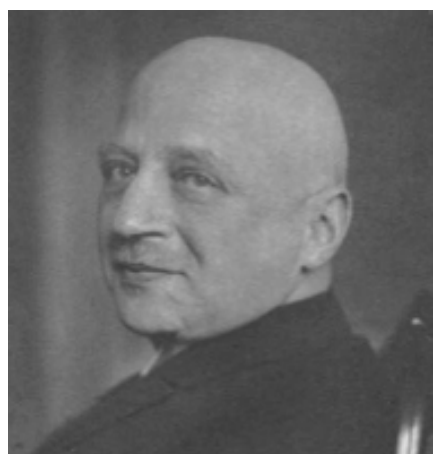

Fritz Haber's discovery of the catalytic synthesis of ammonia from its elements (for which he received the 1918 Nobel Prize in Chemistry) may serve as an apt reminder of the Janus-face of modern science: On one side, "bread from air," on the other, "gunpowder from air." Moreover, in his patriotic zeal during World War One, Haber introduced chemical warfare to the battle field, "poison instead of air," which cast a long shadow over his legacy. The breadth of Haber's intellectual interests was astounding ranging from fundamental physics to physical chemistry to physiology. This was reflected in what had become during the Weimar era of Haber's Kaiser Wilhelm Institute for Physical Chemistry and Electrochemistry, whose exemplary workings entered the annals of the sociology of science. Likewise, the scope of Haber's organizational activities was immense and included the co-founding of the forerunner of the Deutsche Forschungsgemeinshaft and of the Japan Institute. In contrast to many of his colleagues, Haber embraced the Weimar Republic and ranked among its open supporters. Neither his great scientific merits nor his unbridled patriotism sufficed to stave off his loss of status and position once the Nazis rose to power. Haber's Jewish origin as well as his democratic attitudes were a thorn in their flesh. III and bitter, Haber died in exile less than half a year after being driven out of Germany. During the last months of his life he espoused liberal Zionism and made preparations for joining Chaim Weizmann's project of building Jewish academic institutions in Palestine. See also Figure 1. 


\section{Box: Chaim Weizmann (1874-1952)}

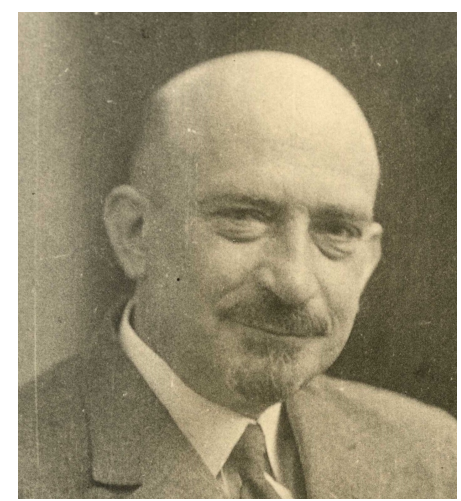

Chaim Weizmann was a renowned biochemist and first President of the State of Israel. With more than two hundred patents, mostly for biochemical processes to produce compounds for a wide range of industries, Weizmann spearheaded the British effort during World War One to mass-produce acetone needed for the production of the smokeless propellant cordite used in British ammunitions. Harnessing his scientific reputation and achievements as well as persuasive personality, Weizmann was able to entice the British political leadership into recognizing through the 1917 Balfour Declaration - the right of the Jewish people to a national home in the land of Israel - then British Mandate Palestine. An active member of the Zionist movement since the early 20th century, Weizmann was elected, after the war, President of the World Zionist Organization, a position he held with brief interruptions -- for more than twenty years. Weizmann focused his efforts on supporting the Jewish community in Palestine by developing ties with the Diaspora as well as on building Jewish academic institutions in Palestine. Among his wide-ranging achievements was the co-founding of The Hebrew University of Jerusalem as well as the establishment of the Daniel Sieff Research Institute in Rehovot, now the Weizmann Institute of Science. After the founding of the State of Israel, to which he contributed in many ways, Weizmann was elected its first president. When he passed away, thousands of mourners descended upon Rehovot to pay their last respects. See also Figure 1. 


\section{Acknowledgments}

The title of this article is intended as an homage to Fritz Stern's 1999 essay "Together and Apart: Fritz Haber and Albert Einstein," which, in our minds, embodies the ideal of a dual biographical account. The title also captures the nature and chronology of Fritz Haber's and Chaim Weizmann's mutual interactions.

We are grateful to Lior Hecht Yacoby (Weizmann Archives) as well as Florian Spillert (Archiv der Max-Planck-Gesellschaft) for their kind assistance. 


\section{References}

\section{A. Books and Journal Articles}

Barry, John M. 2005. "The Great Influenza: The Story of the Deadliest Pandemic in History." London: Penguin Books.

Barth, Boris. 2003. "Dolchstoßlegenden und politische Desintegration. Das Trauma der deutschen Niederlage im Ersten Weltkrieg 1914-1933." Düsseldorf: Droste.

Dean, John. 2004. "Warren G. Harding." in The American Presidents Series. Edited by Arthur M. Schlesinger. New York: Times Books.

Deichmann, Ute and Anthony S. Travis. 2004. Israel Studies 9, 3470.

Friedrich, Bretislav. 2019. Bunsen-Magazin 3/2019, 130-144.

Friedrich, Bretislav and Dieter Hoffmann. 2016. Zeitschrift für Anorganische und Allgemeine Chemie 642, 437-448.

Haber, Fritz and Josef Joshua Weiss. 1934. Proceedings of the Royal Society (London) A417, 332-351. 
Hahn, Ralf. 1999. "Gold aus dem Meer: die Forschungen des Nobelpreisträgers Fritz Haber in den Jahren 1922-1927." Berlin: Verlag für Geschichte der Naturwissenschaften und der Technik.

Illy, Jozsef (ed.). 2006. "Albert Meets America: How Journalists Treated Genius During Einstein's 1921 Travels." Baltimore: Johns Hopkins University Press.

James, Jeremiah and Thomas Steinhauser, Dietrich Hoffmann, and Bretislav Friedrich. 2011. "One Hundred Years at the Intersection of Chemistry and Physics." Berlin: De Gruyter.

Klee, Ernst. 2003. "Das Personenlexikon zum Dritten Reich. Wer war was vor und nach 1945." Frankfurt am Main: Fischer-TaschenbuchVerlag.

Monge, Angeles and Pilar Goya, and José Elguero. 2008. Chemistry International 30, No. 6, http://publications.iupac.org/ci/2008/3006/cc1 230708.html

Rideal, Eric K. 1949. Nature 162, 313.

Stern, Fritz. 2016. "Einstein's German World." Princeton: Princeton University Press.

Stern, Rudolf. 1963. "Fritz Haber: Personal Recollections." The Leo Baeck Institute Year Book, Volume 8, Issue 1, pp. 70-102, https://doi.org/10.1093/leobaeck/8.1.70 
Stoltzenberg, Dietrich. 1998. "Fritz Haber. Chemiker, Nobelpreisträger, Deutscher Jude." Weinheim: Wiley.

Weizmann, Chaim. 1949. "Trial and Error." New York: Harper \& Brothers.

Willstätter, Richard. 1973. "Aus meinem Leben. Von Arbeit, Muße und Freunden." Weinheim: Verlag Chemie.

Wolff, Stefan. 2018. "Haber as a Jewish German Patriot - from Baptism to Zionism", Video https://indico.fhiberlin.mpg.de/event/19/attachments/43/132/VIDEO_5_Stefan_Wolff.mp4

\section{B. Letters}

Albert Einstein to Fritz Haber, 9 March 1921. Archiv der Max-Planck-Gesellschaft, Abt. Va, Rep. 5, 978.

Fritz Haber to Albert Einstein, 9 August 1933.

Archiv der Max-Planck-Gesellschaft, Abt. Va, Rep. 5, 983.

Albert Einstein to Hermann and Marga Haber, after 29 January 1934.

Archiv der Max-Planck-Gesellschaft, Abt. III, Rep. 98, 58. 
Fritz Haber to Carl Bosch, 28 December 1933.

Archiv der Max-Planck-Gesellschaft, Abt. Va, Rep. 5, 911.

Fritz Haber to Hermann and Marga Haber, August 1933.

Archiv der Max-Planck-Gesellschaft, Abt. Va, Rep. 5, 1039.

Fritz Haber to Otto Hahn, 1 October 1933.

Archiv der Max-Planck-Gesellschaft, Abt. Va, Rep. 5,1946.

Fritz Haber to William Pope, 4 August 1933.

Archiv der Max-Planck-Gesellschaft, Abt. Va, Rep. 5, 2321.

Fritz Haber to Bernhard Rust, 30 April 1933.

James, 2011, 95.

Fritz Haber to Chaim Weizmann, 23 December 1932.

Weizmann Archives catalog number 23-1604A.

Fritz Haber to Chaim Weizmann, 1933.

Weizmann Archives catalog number 5-1660.

Fritz Haber to Chaim Weizmann, 21 May 1933.

Weizmann Archives catalog number 2-1636.

Fritz Haber to Chaim Weizmann, August 1933.

Weizmann Archives catalog number 2-1654. 
Fritz Haber to Chaim Weizmann, 24 August 1933.

Weizmann Archives catalog number 15-1658.

Fritz Haber to Chaim Weizmann, 1 October 1933.

Weizmann Archives catalog number 15-1665.

Fritz Haber to Chaim Weizmann, 5 October 1933.

Weizmann Archives catalog number 3-1667.

Fritz Haber to Chaim Weizmann, 15 October 1933.

Weizmann Archives catalog number 2-1669.

Fritz Haber to Chaim Weizmann, 16 November 1933.

Weizmann Archives catalog number 1-1682.

Fritz Haber to Chaim Weizmann, 29 November 1933.

Weizmann Archives catalog number 20-1686A.

Fritz Haber to Chaim Weizmann, 6 January 1934.

Weizmann Archives catalog number 5-1706.

Fritz Haber to Chaim Weizmann, 15 January 1934.

Weizmann Archives catalog number 21-1710A.

Hermann Haber to Chaim Weizmann, 21 May 1933.

Weizmann Archives catalog number 22-1638. 
Hermann Haber to Chaim Weizmann, 26 July 1933.

Weizmann Archives catalog number 13-1652.

Chaim Weizmann to Eva Erleigh, 4 December 1932.

Weizmann Archives catalog number 18-1602.

Chaim Weizmann to Abraham Halevi Frenkel, 5 December 1932.

Weizmann Archives catalog number 2-1603.

Chaim Weizmann to Abraham Halevi Frenkel, 7 December 1932.

Weizmann Archives catalog number 10-1603.

Chaim Weizmann to Ernst David Bergmann, 25 August 1933.

Weizmann Archives catalog number 2-1659.

Chaim Weizmann to Fritz Haber, 2 October 1933.

Weizmann Archives catalog number 14-1665.

Chaim Weizmann to Fritz Haber, 20 October 1933.

Weizmann Archives catalog number 2-1671A.

Chaim Weizmann to Fritz Haber, 10 November 1933.

Weizmann Archives catalog number 5-1680A.

Chaim Weizmann to Fritz Haber, 1 December 1933.

Weizmann Archives catalog number 2-1689. 
Chaim Weizmann to Hermann Haber, 31 January 1934.

Weizmann Archives catalog number 13-1717A.

Chaim Weizmann to Judah Magnes, 5 September 1933.

Weizmann Archives catalog number 19-1660.

Chaim Weizmann to Leonard Ornstein, 13 August 1933.

Weizmann Archives catalog number 21-1656.

Chaim Weizmann to Bruno Rosenfeld, 24 September 1935

Weizmann Archives catalog number 20-1846.

Chaim Weizmann to Richard Willstätter, 10 September 1935.

Weizmann Archives catalog number 10-1843.

Chaim Weizmann to Richard Willstätter, 15 December 1935.

Weizmann Archives catalog number 31-1868A.

\section{Reference to the Weizmann Institute of Science Archives}

Literature appendix 1, individual certificates, 1885-1949, nu. 1275. The Weizmann Institute of Science Archives. 


\section{Note on availability:}

The letters held at the Weizmann Archives are available online at https://www.weizmann-archives.org.il/

\section{Note concerning translations:}

All translations from German into English appearing in this article are our own.

\section{Figure Captions}

Figure 1: Timelines of Fritz Haber's and Chaim Weizmann's lives.

Figure 2: Fritz Haber and Albert Einstein in the stairwell of Haber's Kaiser Wilhelm Institute, circa 1914. On Haber's invitation, Einstein occupied an office there in 1914-1915 (James, 2011, 24).

Figure 3: Zionist delegation to the U.S., 2 April 1921. From left to right: Menachem Ussishkin (head of the Zionist Commission and later President of the Jewish National Fund), Chaim Weizmann, Vera Weizmann, Albert Einstein, Else Einstein, and Ben-Zion Mossenson (Member of the Jewish National Council). Wiki Commons.

Figure 4: Fritz Haber with his best friend, Richard Willstätter, in Kloster, Switzerland, in 1929. Archiv der Max-Planck Gesellschaft. 
Figure 5: Laying of the cornerstone for the library building of the Sieff Institute on 4 April 1935. Weizmann Archives.

Figure 6: Chaim Weizmann in his office at the Sieff Institute in Rehovot. Seated at his desk, Weizmann is flanked by photographs of Fritz Haber and Richard Willstätter. The picture was taken at Weizmann's press conference on 26 February 1945. P. Goldmann, Weizmann Archives.

\section{Additional Photo Credits:}

Box Fritz Haber: Leo Baeck Institute, London.

Box Chaim Weizmann: Weizmann Archives. 


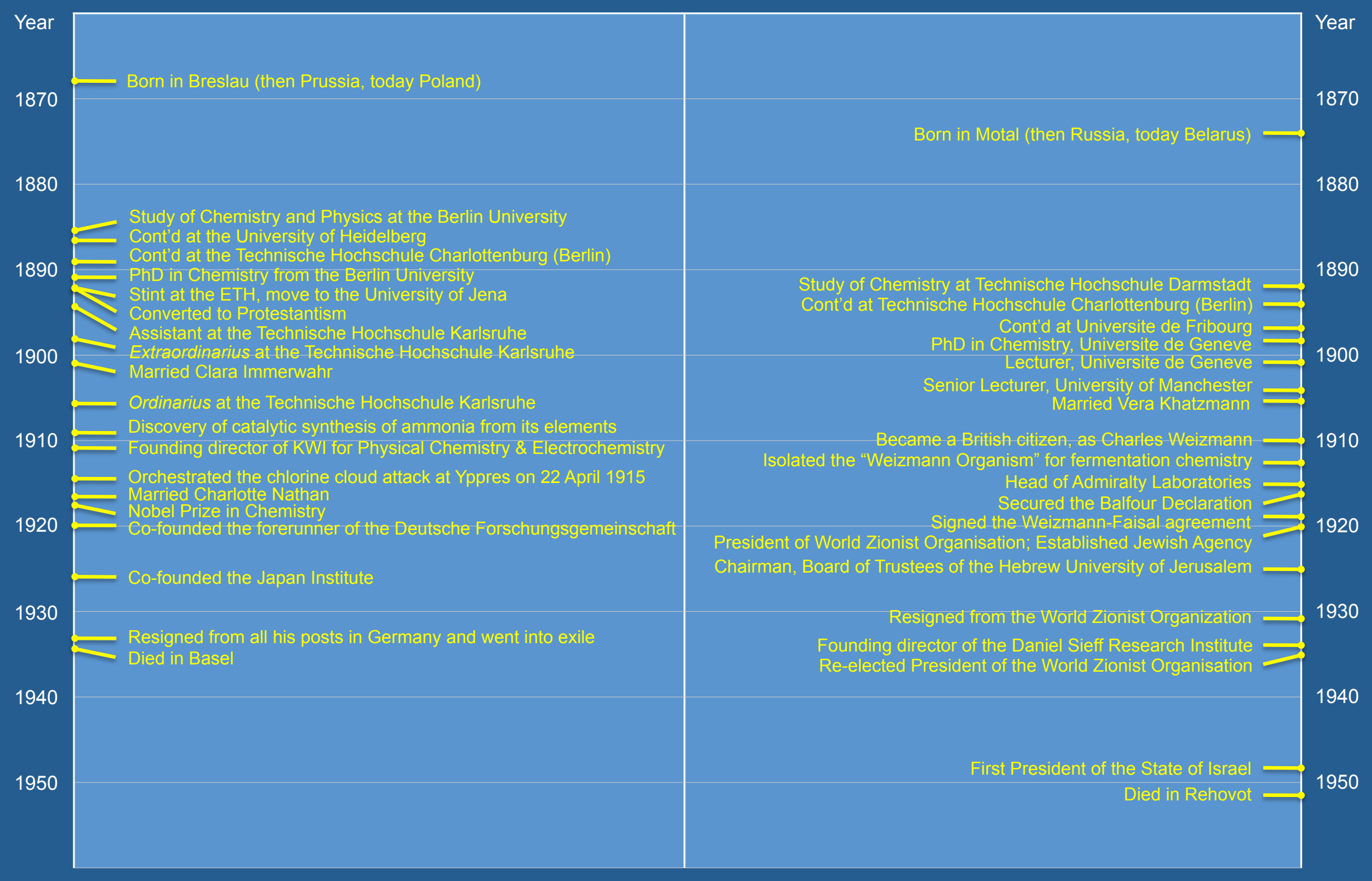

\section{Figure 1}




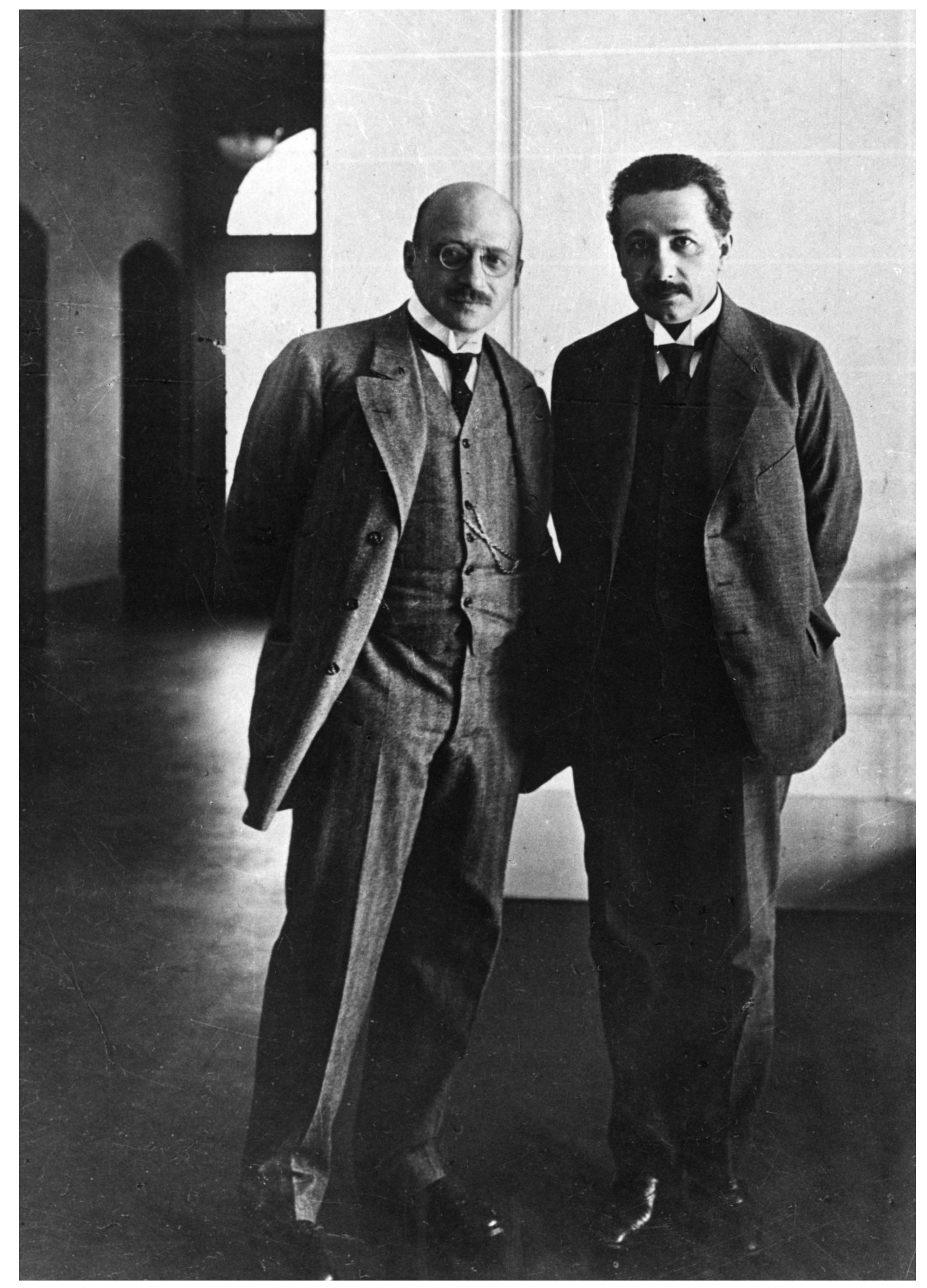

Figure 2 


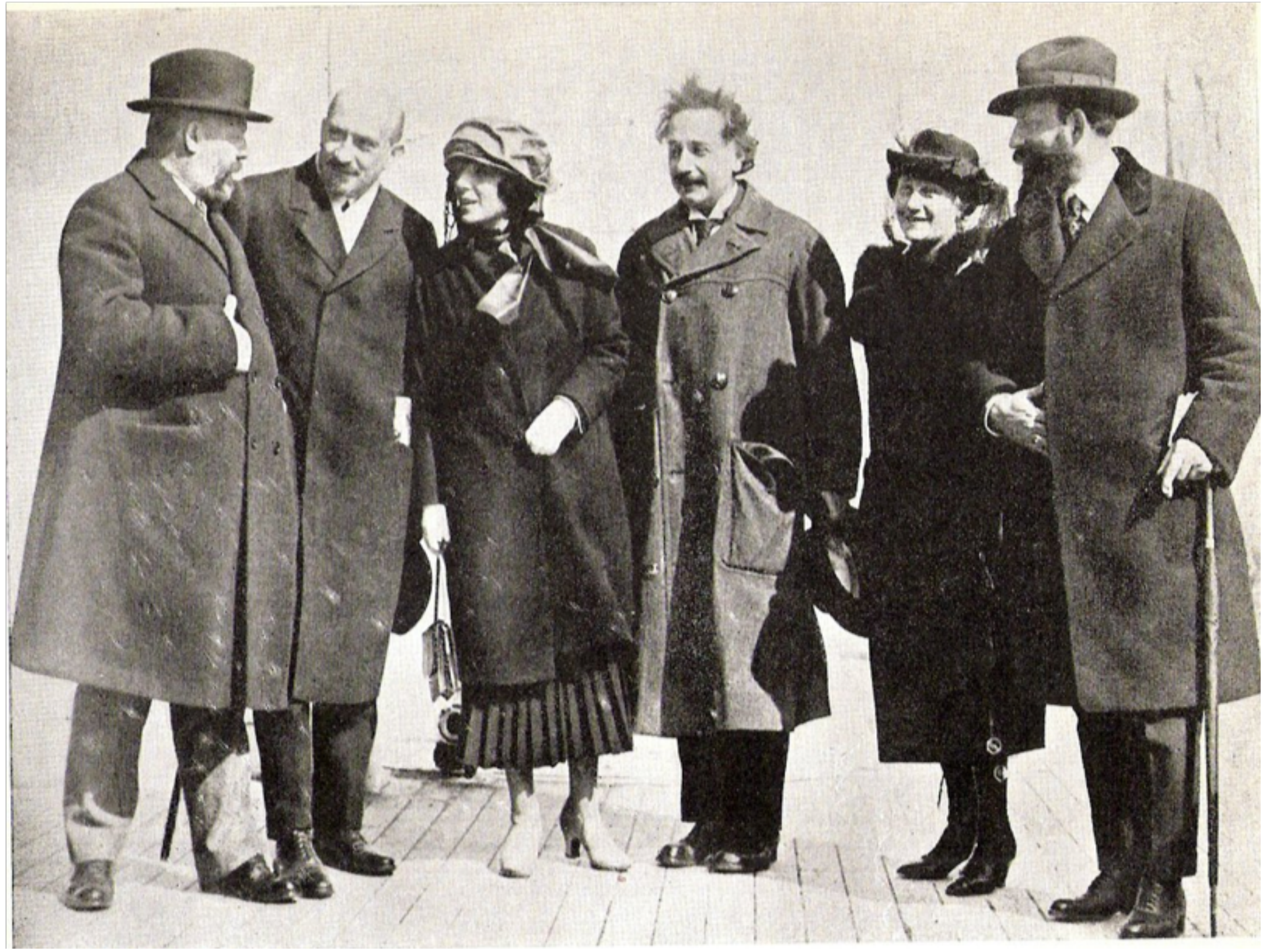

Figure 3 


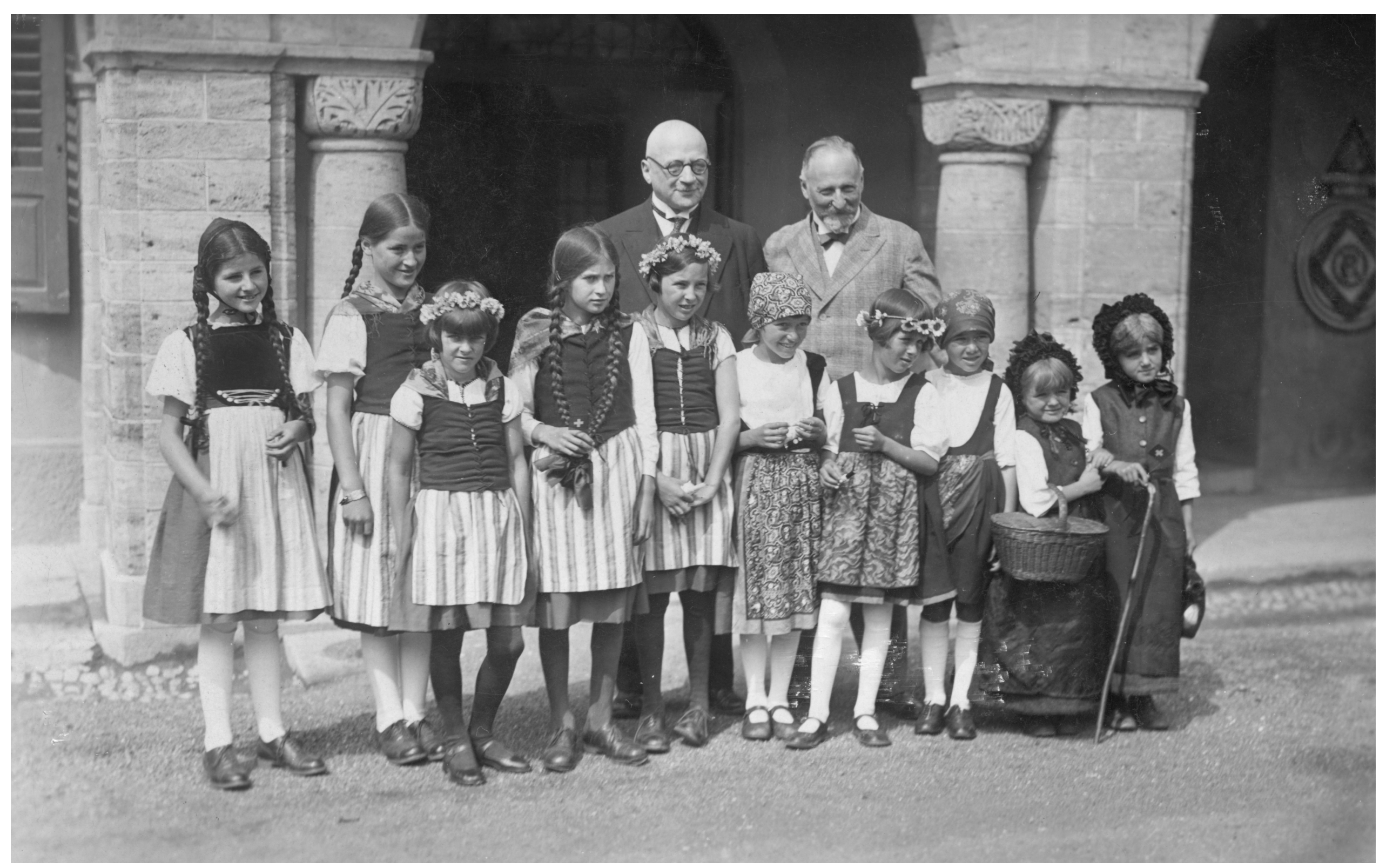

Figure 4 


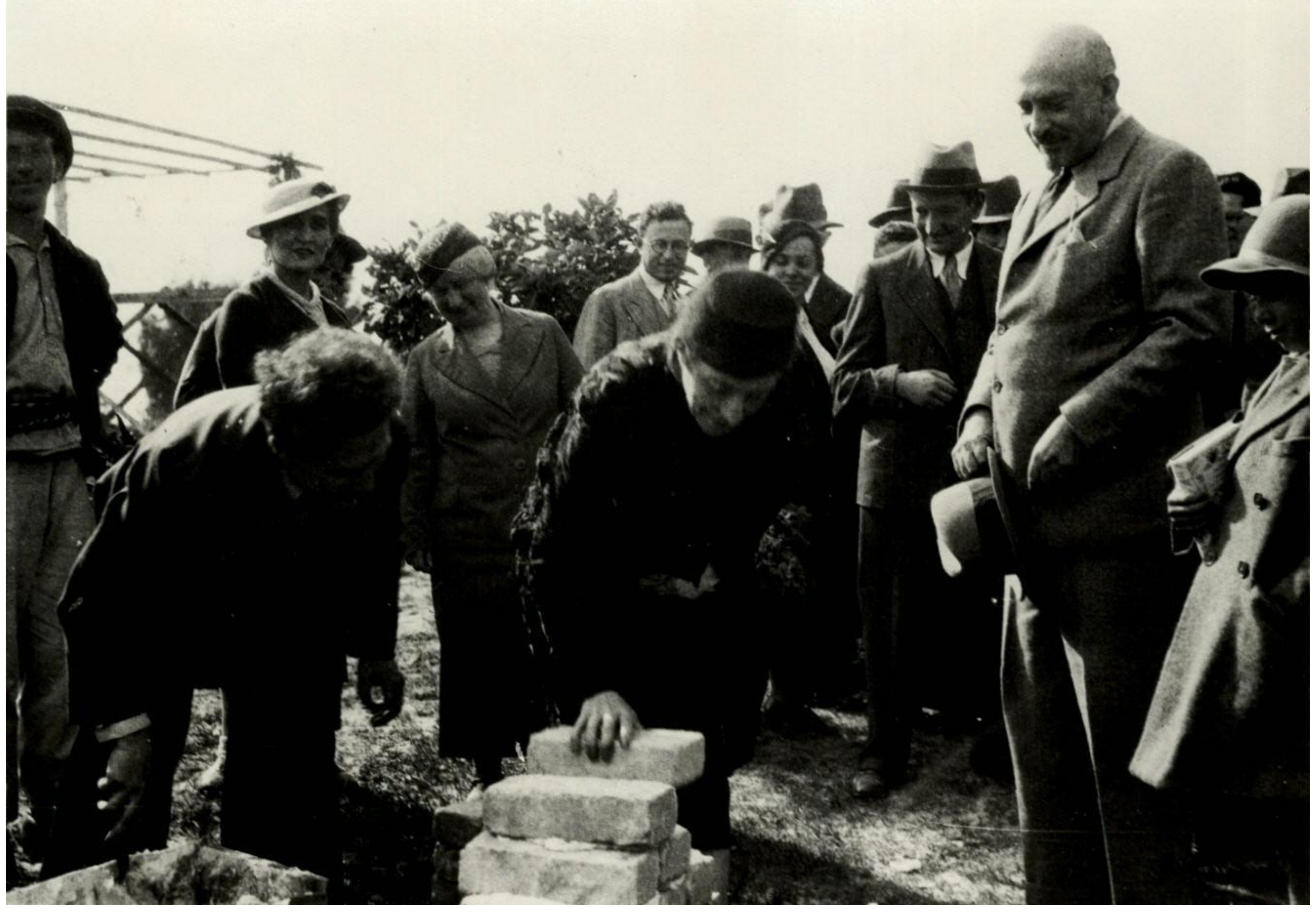

Figure 5 


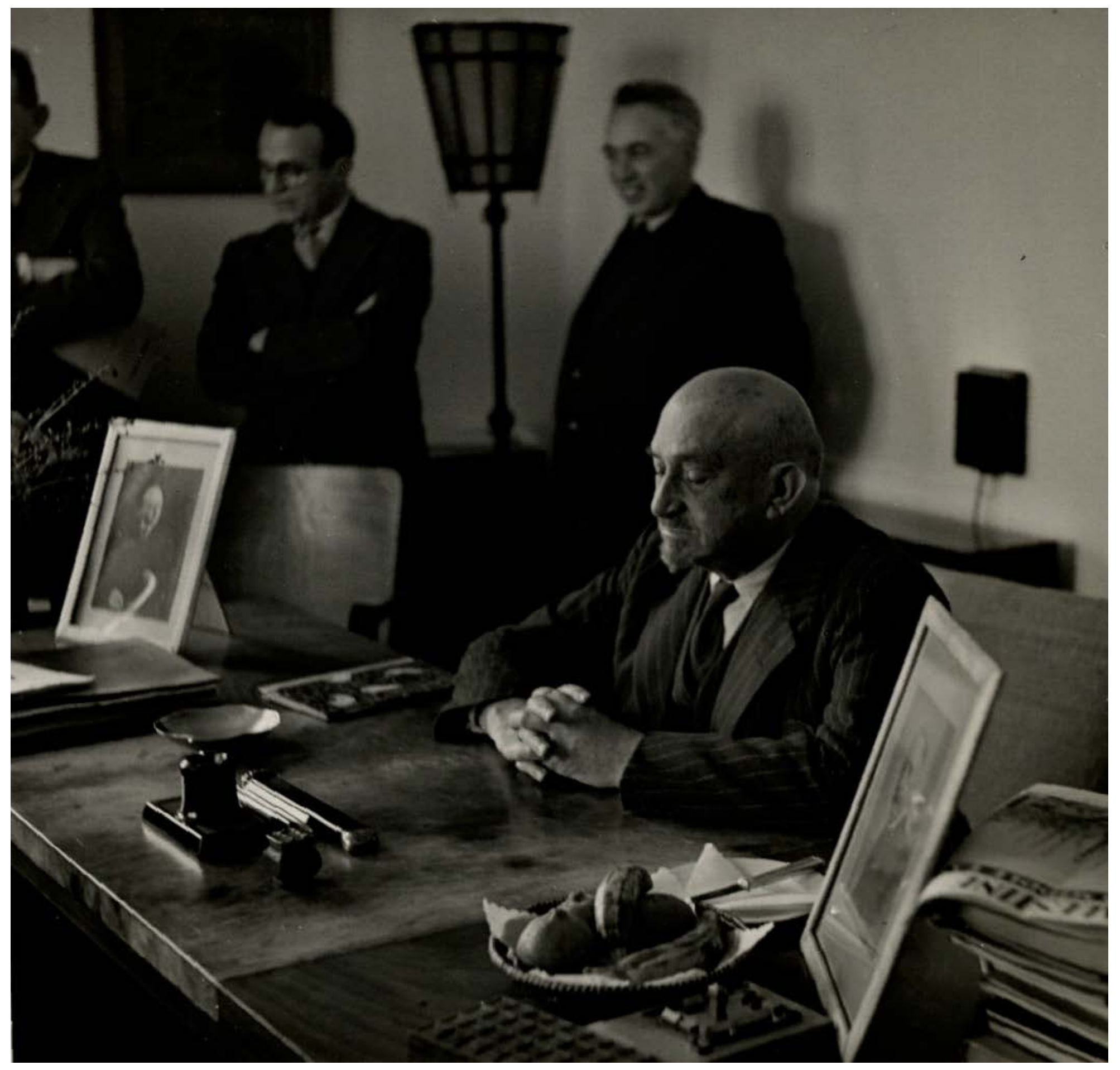

Figure 6 